\title{
Obsessive Neurosis in the Sigmund Freud Approach
}

\author{
Ronaldo Chicre Araujo*, Welerson Silva Carneiro and Gabriel da Costa Duriguetto \\ Department of Psychology, Foundation President Antônio Carlos (FUPAC), Brazil
}

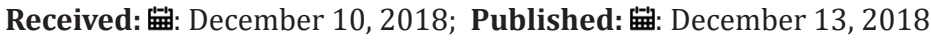

*Corresponding author: Ronaldo Chicre Araujo, Department of Psychology, Foundation President Antônio Carlos (FUPAC), Rua Lincoln Rodrigues Costa, № 165. Brazil

\section{Short Communication}

Obsessive neurosis manifests itself through conjuration rites, obsessing symptoms, and permanent mental rumination, in which scruples and doubts interfere with action. It was the French psychiatrist Jules Falret (1824-1902) who used the term obsession to highlight the fact that the subject is affected by pathological ideas and a guilt that obsesses and persecutes him, to the point of being pejoratively compared to a living dead. The term obsession was translated into German by Richard Von Krafft Ebing, who made the choice to use the word Zwangsneurose, which refers to an idea of coercion and compulsion, in which the subject is obliged to act and think against his will. But it was Freud who had the merit of conferring a theoretical and unpublished content on the old obsession clinic [1].

The obsessive representations are given by the fact that a defense occurs through the separation between an incompatible representation and the affection. The representation remains in the consciousness, in an isolated and weakened way, already the affection, made free, is linked to other representations that, apparently, are not incompatible in themselves. Thanks to this false connection, representations become obsessive representations [2]. In the cases of obsessional neurosis, analyzed by Freud, it was in the sexual life of the subject that aroused distressing affection, precisely an active childhood sexual experience. Early childhood sexual experiences are of great importance in the etiology of obsessional neurosis.

For obsessive patients their thoughts and ceremonies are meaningless and unimportant. What is put into action in an obsessional neurosis is strongly supported by an energy that is found nothing comparable in normal mental life. The thoughts of the obsessive neurotics are so strong that they cannot be prevented from appearing. The only thing the obsessive can do is to displace those absurd thoughts that come from others not so absurd, to exchange tiring rituals for less tiring ones. The obsessive can displace his rites and his obsession, but he cannot remove them.
The possibility of moving any symptom to something distant from its original meaning is one of the main characteristics of the disease [3].

The patient who has a compulsion knows that his obsessive acts have a meaning, but he cannot understand that sense. For him the obsessive act serves to express unconscious motives and ideas and that in them, obsessive acts, there are compulsions and prohibitions, where it is possible to perceive the unconscious feeling of guilt. Obsessive ceremonies arise, in part, as a protection against temptation and partly as protection against the expected evil that will happen if the person does not do this ceremonial. These measures of protection soon appear to be insufficient against temptation and then to prohibitions, the purpose of which is to keep at a distance those situations which may give rise to temptations, and such prohibitions will eventually replace obsessive acts [3].

Compulsion and doubt play an important role in this clinical picture. Doubt corresponds to the patient's inner perception of his own indecision, which, as a consequence of the inhibition of his love through his hatred, takes over from any deliberate action. Doubt leads to repetition of protective measures, in order to drive out uncertainty. The compulsion arises as a way of compensating for doubt, trying to correct the intolerable conditions of inhibition which doubt bears witness to [3]. The obsessive neurotic presents, in his way of existing in the world, traces of ambivalence - another point of agreement with the taboo. Freud affirms that the symptoms, the obsessive acts and the defensive measures are derived from ambivalent impulses. In ambivalence, there is an intense feeling of affection, pity, and intense unconscious hostility. This excessive affection, which seeks to emphasize unconscious hostility, presents itself in the obsessive neurotic as compulsively repeating solicitude. The obsessive neurotic tends to develop a supermorality in order to protect his object love from the hostility that lurks behind him, the origin of this morality being derived from the fact that, in the order of development, hatred is the forerunner of love [4]. 


\section{References}

1. Roudinesco Elisabeth (1998) Dicionário de psicanálise. Rio de Janeiro.

2. Freud Sigmund (1894) As Neuropsicoses de Defesa. Edição standard brasileira das obras psicológicas completas de Sigmund Freud. Rio de Janeiro: Imago 3: 53-65.

\section{ISSN: 2574-1241}

DOI: 10.26717/BJSTR.2018.12.002196

Ronaldo Chicre Araujo. Biomed J Sci \& Tech Res

cC (i) This work is licensed under Creative

Submission Link: https://biomedres.us/submit-manuscript.php
3. Freud S (1907) Atos Obsessivos e Práticas Religiosas. Edição standard brasileira das obras psicológicas completas de Sigmund Freud. Rio de Janeiro: Imago 9: 121-131.

4. Freud Sigmund (1913) A Disposição à Neurose Obsessiva: uma Contribuição ao Problema da Escolha da Neurose. Edição standard brasileira das obras psicológicas completas de Sigmund Freud. Rio de Janeiro: Imago 12: 399-409.

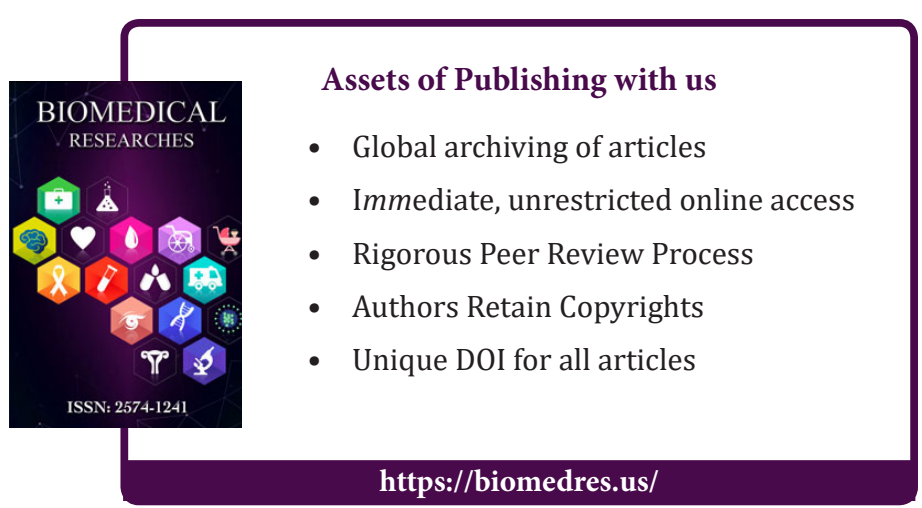

